\begin{tabular}{|c|c|c|c|c|c|c|c|c|c|}
\hline & $\begin{array}{l}\text { Diagnostic criteria } \\
\text { and study period }\end{array}$ & $\begin{array}{c}\mathrm{n} \text { cases / } \\
\text { population size }\end{array}$ & $\begin{array}{c}\text { Mean age } \\
\text { at onset } \\
\text { and sex } \\
\text { (\%female) }\end{array}$ & $\begin{array}{l}\text { Prevalence (over 100000) / } \\
\text { incidence }\end{array}$ & $\begin{array}{l}\text { Oral / gen- } \\
\text { ital ulcers } \\
(\%)\end{array}$ & $\begin{array}{c}\text { Skin } \\
\text { lessions/ } \\
\text { pathergy } \\
\text { test }(\%)\end{array}$ & $\begin{array}{c}\text { Ocular } \\
\text { involve } \\
\text { ment }(\%)\end{array}$ & $\begin{array}{c}\text { Joint } \\
\text { involve } \\
\text { ment (\%) }\end{array}$ & $\begin{array}{c}\text { Neurobehcet/ Vascular/ } \\
\text { Gastrointestinali } \\
\text { nvolvement (\%) }\end{array}$ \\
\hline $\begin{array}{l}\text { Sánchez. L et al. } \\
\text { Southern Europe } \\
\text { (Cantabria, Spain) }\end{array}$ & $\begin{array}{r}\text { Expert opinion, ISG, } \\
\text { ICBD / 1980- } 2020\end{array}$ & $\begin{array}{c}120 \text { (expert opinion) } \\
\text { / } 96 \text { (ICBD) / } 59 \\
\text { (ISG) / 581641 }\end{array}$ & $\begin{array}{c}37.6 \pm 13.8 / \\
48.3\end{array}$ & $\begin{array}{c}20.6 \text { (expert opinion), } 16.5 \\
\text { (ICBD), } 10.1 \text { (ISG)/ } 0.022 \\
\text { (expert opinion), } 0.018 \text { (ICBD), } \\
0.011 \text { (ISG) }\end{array}$ & $94.2 / 59.2$ & $63.3 / 25.2$ & 41.6 & 65 & $10.8 / 11.6 / 6.6$ \\
\hline $\begin{array}{l}\text { Calamia, K. T. et al. } \\
\text { North America } \\
\text { (Minnesota, USA) }\end{array}$ & ISG / 1960-2005 & $13 / N R$ & $31 / 30$ & $5.2 / 0.38$ & $100 / 62$ & $85 / N R$ & 62 & 46 & $23 / 23 / N R$ \\
\hline $\begin{array}{l}\text { Altenburg, A. et al. } \\
\text { Northern Europe } \\
\text { (Berlin, Germany) }\end{array}$ & $\begin{array}{l}\text { ISG and ABD } \\
\text { classification tree / } \\
1961-2005\end{array}$ & $590 / 3391344$ & $26 / 58$ & $4.9 / 1$ (estimated) & $98.5 / 63.7$ & $62.5 / 33.7$ & 58.1 & 53 & $10.9 / 22.7 / 11.6$ \\
\hline $\begin{array}{l}\text { Mohammad, A. et al. } \\
\text { Northern Europe } \\
\text { (Skane County, } \\
\text { Sweden) }\end{array}$ & ISG / 1997-2010 & $40 / 809317$ & $30.5 / 33$ & $4.9 / 0.2$ & $100 / 80$ & $88 / N R$ & 53 & 40 & $0 / 20 / N R$ \\
\hline $\begin{array}{l}\text { Mahr, A. et al. Southern } \\
\text { Europe (SeineSaint- } \\
\text { Denis County, France) }\end{array}$ & ISG / 2003 & 79 / 1094412 & $27.6 / 43$ & $7.1 / \mathrm{NR}$ & $100 / 80$ & $90 / 20$ & 51 & 59 & $10 / \mathrm{NR} / 10$ \\
\hline $\begin{array}{l}\text { Salvarani, C. et al. } \\
\text { SouthernEurope } \\
\text { (Reggio Emilia, Italy) }\end{array}$ & ISG, 1988-2005 & $18 / 486961$ & $33 / 50$ & $3.7 / 0.24$ & $100 / 78$ & $100 / \mathrm{NR}$ & 56 & 50 & $11 / 6 / N R$ \\
\hline $\begin{array}{l}\text { Azizlerli, G. et al. Middle } \\
\text { East (Istambul, } \\
\text { Turkey) }\end{array}$ & $\begin{array}{c}\text { ISG / prevalence } \\
\text { study }\end{array}$ & $101 / 23986$ & NR / 48.5 & 42 / NR & $100 / 70.2$ & $\begin{array}{c}\text { Not globally } \\
\text { reported / } \\
69.3\end{array}$ & 27.7 & $\begin{array}{l}\text { Not } \\
\text { globally } \\
\text { reported }\end{array}$ & $\begin{array}{l}\text { NR / Not globally } \\
\text { reported / NR }\end{array}$ \\
\hline $\begin{array}{l}\text { Davatchi, F. et al. Middle } \\
\text { East (Iran nationwide) }\end{array}$ & $\begin{array}{c}\text { Expert opinion / } \\
1975-2018\end{array}$ & 7641 / NR & $25.6 / 44.2$ & $80 / N R$ & $97.5 / 64.4$ & $62.2 / 50.4$ & 55.6 & 38.1 & $3.9 / 8.9 / 6.8$ \\
\hline $\begin{array}{l}\text { Krause, I. et al. Middle } \\
\text { East (Galilee, Israel) }\end{array}$ & $\begin{array}{c}\text { ISG / } 15 \text { years (not } \\
\text { specific years have } \\
\text { been reported) }\end{array}$ & $112 / 737000$ & $30.6 / 47$ & 15.2 / NR & NR / 68 & $41 / 44.4$ & 58 & 70 & $\begin{array}{l}11.6 \text { / Not globally } \\
\text { reported / NR }\end{array}$ \\
\hline $\begin{array}{l}\text { Nishiyama, M. et al. Asia } \\
\text { (Japan nationwide) }\end{array}$ & 1987 JCBD / 1991 & 3316 / NR & $35.7 / 50.6$ & NR / NR & 98.2 / 73.2 & $87.1 / 43.8$ & 69.1 & 56.9 & $11 / 8.9 / 15.5$ \\
\hline
\end{tabular}

JCBD: Japanese diagnostic Criteria of Behçet's Disease; $n$ : number of cases; NR: Not Reported

Objectives: In a well-defined Northern Spanish population-based cohort, the aim of this study was a) to estimate epidemiological variations, b) clinical domains and $\mathbf{c}$ ) to compare our results with other regions.

Methods: Study of unselected all consecutive patients diagnosed with definitive or possible BD by expert rheumatologists between 1980 and 2020 in our health region. Two classification criteria were applied: a) International Study Group (ISG) for BD [1], and b) International Criteria for BD (ICBD) [2]. In addition, a literature review of Medline publications was carried out.

Results: In this study, from a total of 120 patients diagnosed with BD by expert opinion (58 women/62 men), 96 met ICBD and 59 ISG criteria. Mean age of the cohort at diagnosis was $37.6 \pm 13.8$ years similar to other countries, as well as sex distribution.

Prevalence was higher than in most European populations regardless the diagnostic criteria applied: expert opinion (20.6), ICBD (16.5) or ISG (10.1) (TABLE 1). Incidence was lower (expert opinion: 0.022, ICBD: 0.018, ISG: 0.011 ). Clinical domains' frequency was in line with other regions except vascular and gastrointestinal involvement, which were lower.

Conclusion: BD's prevalence in Northern Spain is higher than in most European populations. These differences likely reflect a combination of true geographic variation, methodological artifacts as well as the easy access to Public Health System and its efficiency. In contrast, clinical phenotypes are similar to other regions. REFERENCES:

[1] Lancet. 1990; 335:1078-80

[2] J Eur Acad Dermatol Venereol. 2014; 28:338-47

Disclosure of Interests: Lara Sanchez-Bilbao: None declared, Guillermo Suárez-Amorín: None declared, Carmen Álvarez-Reguera: None declared, Alba Herrero-Morant: None declared, David Martínez-López: None declared, José Luis Martín-Varillas: None declared, M. Cristina Mata Arnaiz: None declared, Rosalía Demetrio-Pablo: None declared, Miguel A González-Gay Speakers bureau: AbbVie, Pfizer, Roche, Sanofi, Celgene and MSD., Grant/research support from: AbbVie, MSD, Jansen and Roche, Ricardo Blanco Speakers bureau: AbbVie, Pfizer, Roche, Bristol-Myers, Janssen, Lilly and MSD., Grant/research support from: AbbVie, MSD and Roche.

DOI: 10.1136/annrheumdis-2021-eular.3577

\section{AB0400 URINARY ALBUMIN-TO-CREATININE RATIO INDICATES NECROTIZING AND CRESCENTIC GLOMERULONEPHRITISIN ANCA-ASSOCIATED VASCULITIS}

S. Hakroush ${ }^{1}$, B. Tampe ${ }^{2}{ }^{1}$ University Medical Center Göttingen, Institute of Pathology, Göttingen, Germany; ${ }^{2}$ University Medical Center Göttingen, Department of Nephrology and Rheumatology, Göttingen, Germany
Background: Renal involvement is a common and severe complication of anti-neutrophil cytoplasmic antibody (ANCA)-associated vasculitis (AAV) as it can cause acute kidney injury (AKI), end-stage renal disease (ESRD) or death. Objectives: We have previously reported that elevated urinary albumin-to-creatinine ratio (UACR) correlates with rapid deterioration of kidney function in ANCA GN. Therefore, we here aimed to describe the association between proteinuric findings and histopathological diagnosis of necrotizing and crescentic ANCA GN in 50 urinary samples at admission and corresponding renal biopsies of patients with AAV.

Methods: A total number of 50 urinary samples at admission and corresponding renal biopsies with confirmed renal involvement of AAV were retrospectively included between 2015 till 2020 in a single-center observational study.

Results: Renal involvement of AAV revealed variable proteinuria ranging from low-range to nephrotic syndromes, however most patients presented with subnephrotic proteinuria. Severe deterioration of kidney function requiring RRT within 30 days after admission was associated with elevated levels of nonselective proteinuria, mostly attributed to albuminuria (UACR). Because we have previously shown that histologically confirmed ANCA GN with glomerular crescents and necrosis is associated with AKI and requirement of RRT during short-term disease course and elevated UACR levels were equally associated with $\mathrm{AKI}$ and requirement of RRT during the short-term course after disease onset, we next analyzed the association between UACR measurements at admission and histopathological findings within renal biopsies performed thereafter. Severely increased UACR levels $>300 \mathrm{mg} / \mathrm{g}$ correlated with reduction of normal glomeruli, attributed to increased glomerular crescents and necrosis. By contrast, no such association was observed for global sclerotic glomeruli, revealing that uACR reflects crescentic ANCA GN rather than adaptive glomerular hyperfilitration in chronic sclerosing stage. Since uACR levels could reflect both, either a specific renal involvement with necrotizing and crescentic ANCA GN or severity of systemic AAV disease, we next correlated UACR levels assessed at admission with extrarenal disease manifestation. We observed no association between UACR levels and extrarenal manifestation of AAV disease including pulmonary hemorrhage, skin involvement and BVAS assessment, suggesting that UACR levels reflected specific renal involvement in AAV. These observations were further confirmed by survival analysis for cumulative incidence of RRT during the short-term course of disease.

Conclusion: Early identification of patients who mostly benefit from aggressive immunosuppressive therapy is of clinical importance. Our observation that UACR levels at disease onset predict necrotizing and crescentic ANCA GN requires further investigation for therapeutic decision especially in patients with severe deterioration of kidney function.

Disclosure of Interests: None declared

DOI: 10.1136/annrheumdis-2021-eular.4298 